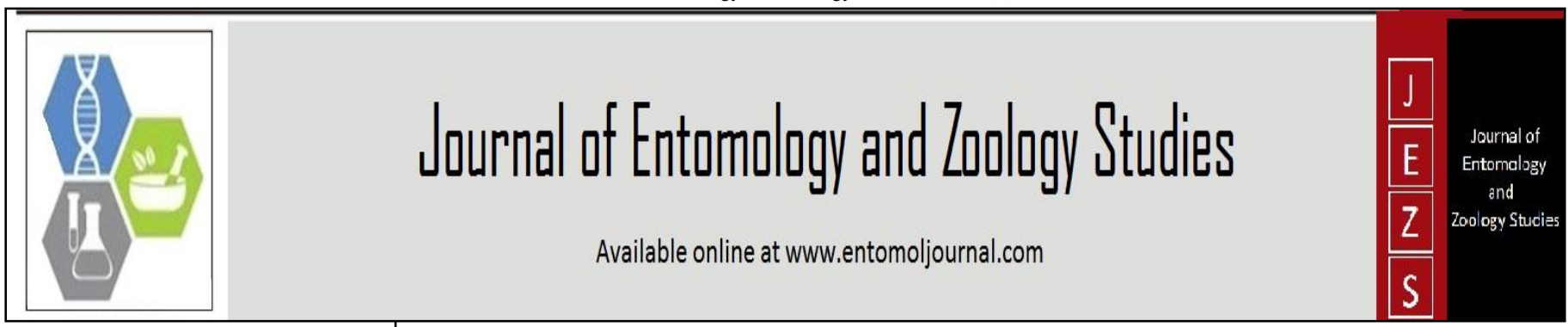

E-ISSN: 2320-7078 P-ISSN: 2349-6800 www.entomoljournal.com JEZS 2021; 9(5): 253-256 (C) 2021 JEZS

Received: 28-07-2021 Accepted: 30-08-2021

Ashaolu Victoria Oladimeji Research Scholar, Department of Chemistry, LIFE, Loyola College, Chennai, Tamil Nadu, India
Corresponding Author: Ashaolu Victoria Oladimeji Research Scholar, Department of Chemistry, LIFE, Loyola College, Chennai, Tamil Nadu, India

\section{Bioaccumulation of heavy metals in edible foods in Osun River}

\section{Ashaolu Victoria Oladimeji}

DOI: https://doi.org/10.22271/j.ento.2021.v9.i5c.8835

\title{
Abstract
}

Heavy metals are present naturally in relatively low amounts in the earth's crust. But there is an increased alarming rate over the years of heavy metals present in water bodies and in turn aquatic life which has resulted to food poisoning. Trace amounts of some heavy metals, such as Manganese, calcium zinc, and potassium, are key to maintaining the metabolism of the human body but in high concentration could be considered as Metal pollution. Heavy metals can cause poisonings resulting in impaired mental and central nervous function, as well as damage to vital organs. Long-term exposure may result in slowly progressing physical, muscular, and neurological degenerative conditions including cancer. The Food and Drug Administration (FDA) enforces action levels for poisonous or deleterious substances in human food and animal feed, including cadmium, lead, mercury, and others from water bodies. Based on this report, Samples of edible foods such as fishes and crabs were obtained from five different locations in Osun River based on activities carried out daily. Results obtained proved that no heavy metal is present in edible foods at Osun river which makes it suitable and recommended for consumption.

Keywords: heavy metals, metal pollution, water bodies, edible foods, Osun river

\section{Introduction}

Aquatic animals such as fishes, crabs, prawns etc. have their own way of life which makes it possible for them to live in water. For instance, their way of feeding, swimming and reproduction is known as adaptation. Some animals have streamlined bodies so as to swim well; others have very light weight for the same swimming purpose ${ }^{[2]}$.

Several researches revealed heavy metal content in crustacean. The source of the heavy metals in them, and the toxic effect of the heavy content in crustaceans and the effects on man who in turn consume the crustacean ${ }^{[2]}$. Although many heavy metals are essential for animal tissues metabolism, the ranges between beneficial and toxic heavy metals are very small. There is an increasing concern about the health effect in human due to continuous consumption of food contaminated with heavy metals and the extent of this contamination depends on several complex factors, one of which is the specific metabolic and homeostatic mechanisms operating in the type of food and tissue considered ${ }^{[4]}$.

However, all these and several others informed my decision to research on this topic Heavy metals which are introduced into aquatic environment through domestic and industrial waste discharge into water body. It is rather of great concern that over $80 \%$ Of the industries in Nigeria dispose Heavy metal such as cadmium, lead, copper, zinc and nickel into the environment without any prior treatment while just only $18 \%$ of undertake rudimentary recycling prior to disposal is augmented ${ }^{[6]}$. Agricultural activities also contributed to the pollution or the aquatic environment through run off which find their ways into the water bodies ${ }^{[5]}$.

The factors which contribute principally to the damaging effect of metal as environmental pollutants are, firstly, their inadequate biological degradation to inert metals and secondly. the trend of metals to accumulate and largely remain in the aquatic environment ${ }^{[5]}$. Sediments have been reported to form the major repository of heavy metals in aquatic system while both allochthonous and autochthonous influences could make concentration of heavy metals in the water high enough to be of ecological significance ${ }^{[1]}$. 
Metal pollution has become a major international issue since the 1960(s) when thousands of people were poisoned in Minamaten, Japan after consuming mercury-polluted sea foods. Some researchers affirmed main sources of metal pollution are domestic/industrial sewage. Industrial effluents, oil and chemical spills, combustion emission. mining operations. Metallurgical activities and non-hazardous landfill sites ${ }^{[6]}$. Pb enters the Aquatic environment through erosion and leaching from the soil, $\mathrm{Pb}$-dust fallouts from the atmosphere. combustion of petrol, domestic and industrial waste discharges, runoff of fallout deposits from roads and other surface as well as precipitation ${ }^{[1,2]}$.

Increasing concentrations of the metals $\mathrm{Pb}$ and $\mathrm{Zn}$ cause significant increases in the mortality in edible foods in rivers. Increasing $\mathrm{Pb}$ and $\mathrm{Zn}$ concentrations in permutation with varying salinities exhibit a significant negative influence on crustacean development ${ }^{[1]}$. All these problems and several others concurrently compelled my decision to research in this area and also to find thorough ways of completely eradicating or preferably reducing the incidence of heavy metals on edible foods in rivers.

\section{Aims and objectives}

The aim of this work is therefore to determine the heavy metals concentration in edible animals in Osun River and also to postulate workable research solution that can be of wider applicability.

\section{Materials and Method \\ Sample Collection}

Samples of edible foods such as fishes and crabs were obtained from five different locations in Osun River based on activities carried out daily.

\section{Sampling method}

Sampling was carried out in accordance with the recommendation of the UNEP (United Nations Environment Programme) reference method for marine pollution studies. The samples of soil and edible foods were collected from Osun River weekly for a period of five weeks using FishingDrag Net.30 at five different locations in view of the activities spanning the length of the river.

\section{Samples Preparation of Edible Foods}

The three varieties of fishes and crabs obtained were collected, rinsed and drained under folds of filters; weighed and then frozen at $50{ }^{\circ} \mathrm{C}$ prior to analysis. Samples from the various locations were homogenized using manual method i.e. mortar and pestle, and then undergo digestion before it is ready to be used for the experiments

\section{Proximate Analysis}

This is the routine analysis of aquatic tissue that is done to examine its composition.

\section{Determination of Moisture Content}

A $2 \mathrm{~g}$ of sample was weighed $\left(\mathrm{W}_{2}\right)$ into a previously dried $\left(150{ }^{\circ} \mathrm{C}\right)$ and weighed metal can with lid $\left(\mathrm{W}_{1}\right)$. Sample was dried in the Oven with lid unfitted at $105{ }^{\circ} \mathrm{C}$ for 5 hours. Sample was removed from Oven; lid fitted and cooled in a desiccator for at least 30 minutes and reweighed $\left(\mathrm{W}_{3}\right)$.

$$
\% \text { Moisture Content }=\frac{\text { Oven dry sample- Weight of empty can } \cdot 100 \%}{\text { Weight of sample-Weight of empty can }}
$$

\section{Determination of Dry Ash Digestion and Analysis}

About $0.48 \mathrm{~g}-0.52 \mathrm{~g}$ sample was weighed into a clean ceramic crucible, weight was to the nearest $0.001 \mathrm{~g}$. One empty crucible was included for a blank. It was placed in a cool muffle furnace and ramp temperature to $500{ }^{\circ} \mathrm{C}$, it was then allowed to cool down in the oven. Sample was removed from the oven making sure that the environment is free from breeze. Shed sample was poured first into an already numbered or labelled $50 \mathrm{ml}$ centrifugal tube. Crucible was rinsed firstly with $5 \mathrm{ml}$ of distilled water, then another $5 \mathrm{ml}$ of aqua regia. Procedure was repeated to make a total volume of $20 \mathrm{ml}$. Samples were centrifuged for I0mins at $3000 \mathrm{rpm}$. Supernatant were decanted into clean vials for macro and micro nutrient determination using atomic absorption spectrophotometer. This procedure was used for analysis of $\mathrm{P}$, $\mathrm{Ca}, \mathrm{Mg}, \mathrm{K}, \mathrm{Na}, \mathrm{Zn}, \mathrm{Cu}, \mathrm{Mn}, \mathrm{Fe}$, and $\mathrm{N}$.

\section{Results}

Table 1: Chemical Properties of Edible Foods in Osun River

\begin{tabular}{|c|c|c|c|c|}
\hline Parameters & Catfish $^{\mathrm{T}}$ & Tilapia fish & Electric fish & Crab \\
\hline$\% \mathrm{~N}$ & $8.14 \pm 0.02^{\mathrm{c}}$ & $8.14 \pm 0.02^{\mathrm{c}}$ & $8.30 \pm 0.01^{\mathrm{c}}$ & $3.87 \pm 0.02^{\mathrm{b}}$ \\
\hline$\% \mathrm{P}$ & $2.05 \pm 0.01^{\mathrm{b}}$ & $2.79 \pm 0.01^{\mathrm{c}}$ & $1.80 \pm 0.01^{\mathrm{b}}$ & $0.95 \pm 0.03^{\mathrm{a}}$ \\
\hline$\% \mathrm{MC}$ & $0.96 \pm 0.01^{\mathrm{b}}$ & $1.56 \pm 0.02^{\mathrm{b}}$ & $1.75 \pm 0.02^{\mathrm{c}}$ & $0.35 \pm 0.005^{\mathrm{a}}$ \\
\hline Protein & $53.47 \pm 0.1^{\mathrm{c}}$ & $50.89 \pm 0.01^{\mathrm{b}}$ & $51.92 \pm 0.01^{\mathrm{b}}$ & $29.63 \pm 0.01^{\mathrm{a}}$ \\
\hline
\end{tabular}

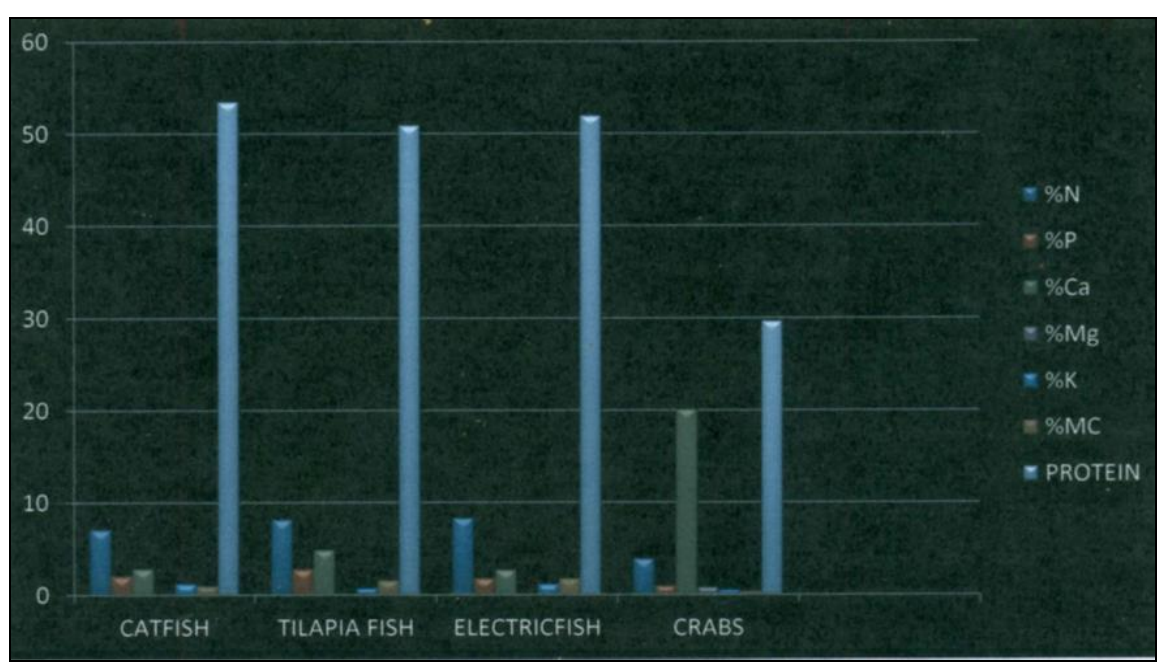

Fig 1: Graphical Representation of Chemical Composition of Edible Food in Osun River 
From the analytical result obtained, amount of nitrogen and phosphorus within fishes are relatively close, which is within standard of WHO except in the case of crab which is of a reduced quantity.

About $2.5 \%$ of the weight of living organisms comes from Nitrogen in organic molecules. It can also be relatively seen that the volume of moisture contents presents in both fishes and crab is very small. Since water aid digestion, aquatic foods cannot be recommended to everyone, especially those who have constipation in order to assist in elimination of waste from the body through excretion. Water also regulates body temperature and prevents dehydration. Since protein is needed as part of the requirement for body building, the result obtained shows that catfish possess highest concentration of protein and should be recommended for adequate consumption.
Table 2: Trace/Heavy metals in Edible foods

\begin{tabular}{|c|c|c|c|c|}
\hline Parameters & Catfish & Tilapia fish & Electric fish & Crab \\
\hline $\mathrm{Ca}$ & $2.83 \pm 0.005^{\mathrm{a}}$ & $4.86 \pm 0.03^{\mathrm{b}}$ & $2.68 \pm 0.02^{\mathrm{a}}$ & $20.05 \pm 0.01^{\mathrm{c}}$ \\
\hline $\mathrm{Mg}$ & $0.11 \pm 0.02^{\mathrm{a}}$ & $0.13 \pm 0.02^{\mathrm{a}}$ & $0.11 \pm 0.02^{\mathrm{a}}$ & $0.79 \pm 0.01^{\mathrm{c}}$ \\
\hline $\mathrm{K}$ & $1.19 \pm 0.04-\mathrm{c}$ & $0.70 \pm 0.01^{\mathrm{b}}$ & $1.12 \pm 0.0^{\mathrm{c}}$ & $0.47 \pm 0.01^{\mathrm{d}}$ \\
\hline $\mathrm{Na}$ & $138.54 \pm 0.02^{\mathrm{c}}$ & $86.49 \pm 0.11^{\mathrm{b}}$ & $120.26 \pm 1.16^{\mathrm{c}}$ & $166.14 \pm 0.01^{\mathrm{d}}$ \\
\hline $\mathrm{Mn}$ & $14.19 \pm 0.01^{\mathrm{a}}$ & $63.34 \pm 0.02^{\mathrm{b}}$ & $43.51 \pm 0.02^{\mathrm{b}}$ & $293.36 \pm 0.02^{\mathrm{d}}$ \\
\hline $\mathrm{Fe}$ & $43.36 \pm 0.01^{\mathrm{b}}$ & $79.13 \pm 0.02^{\mathrm{c}}$ & $34.69 \pm 0.03^{\mathrm{b}}$ & $209.18 \pm 0.03^{\mathrm{d}}$ \\
\hline $\mathrm{Cu}$ & $1.35 \pm 005^{\mathrm{a}}$ & $1.55 \pm 0.02^{\mathrm{a}}$ & $1.25 \pm 0.01^{\mathrm{a}}$ & $10.42 \pm 0.02^{\mathrm{b}}$ \\
\hline $\mathrm{Zn}$ & $18.40 \pm 0.02^{\mathrm{b}}$ & $19.34 \pm 0.01^{\mathrm{b}}$ & $18.23 \pm 0.02^{\mathrm{b}}$ & $24.89 \pm 0.01^{\mathrm{d}}$ \\
\hline $\mathrm{Cd}$ & $\mathrm{ND}$ & ND & ND & ND \\
\hline $\mathrm{Pb}$ & ND & ND & ND & ND \\
\hline $\mathrm{Cr}$ & ND & ND & ND & ND \\
\hline $\mathrm{Se}$ & ND & ND & ND & ND \\
\hline $\mathrm{Ni}$ & ND & ND & ND & ND \\
\hline $\mathrm{Co}$ & ND & ND & ND & ND \\
\hline
\end{tabular}

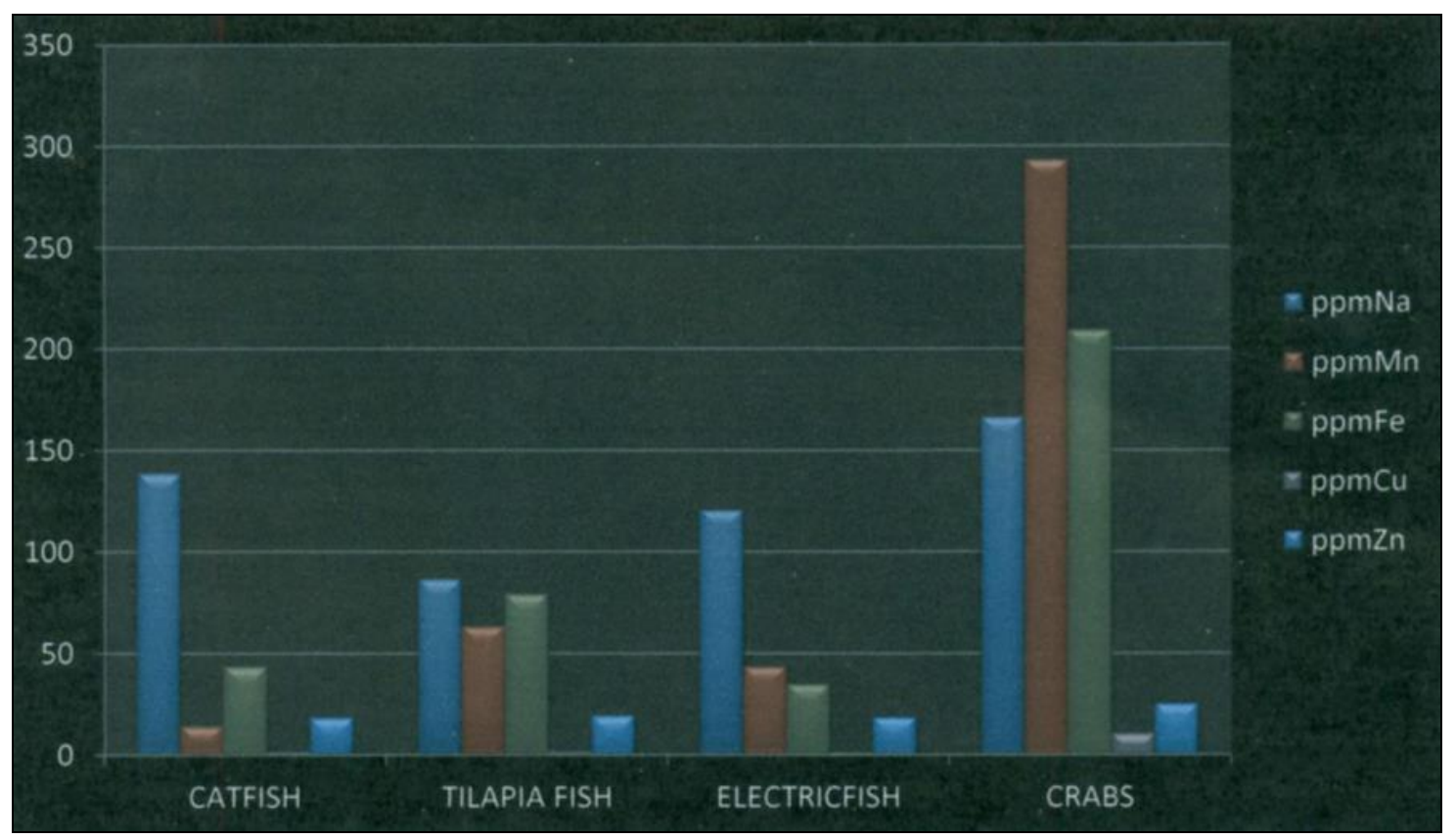

Fig 2: Graphical Representation of Trace Metals of Edible Food

Tables and Figures shows comparisons of the analysis of different species of fish in Osun River. Table 1 and 2 focus on the concentration of analytes such as trace/heavy metal determination in both crab and fishes. From the results, the table 1 shows that Catfish possess the highest concentration of protein followed by Electric fish and Tilapia fish including crab. Fig. 2 also illustrates that crab has the highest concentration of Manganese, followed by tilapia fish, electric fish and catfish respectively. The same level of accumulation in fishes was quite different from the crab. Table 2 show that crabs in Osun River are rich in calcium, iron, and sodium. This makes it highly recommended for moderate consumption. High sodium contributes to high blood pressure so people with high blood pressure should not take in more of crabs. Metal accumulation are of reduced value in fishes and crab. This can be due to non-agricultural activities carried out in the river and its surrounding.

\section{Discussion}

Fishes are an important source of food and represent a major part of many natural food chains. Therefore, the levels of contaminants in edible foods are of particular interest because of the potential effects of these polluting substances on the fish themselves and on the organisms that consume them, including humans ${ }^{[3]}$. These studies cannot give realistic information about heavy metal pollution because seafoods are migratory species. Based on the results analysed above, there are little or no heavy metal in edible foods which comply to the WHO standard of water quality ${ }^{[9]}$. There are currently no registered human poisoning cases related to Heavy metal pollution in the localized area of study. The lack of such data may be partly related to belief system and poor clinical analysis with no attention to recognize signs/symptoms of heavy metal poisoning in humans. Crabs however, in Osun river should be recommended for moderate consumption. Values obtained from the result shows that crabs are very rich in zinc; Zinc is very important in the diet because it is a constituent of insulin and of many enzymes in the body. Consequently, it can be concluded that heavy metals and minerals present are within the permissible level of consumption ${ }^{[5]}$. Undoubtably, with the rise in urban planning and constructions, the aquaculture system of most consumed seafood species is strongly recommended, to avoid or minimize the consumption of contaminated seafood.

\section{Conclusion}

In conclusion, these observations may be due to the major functional differences in water bodies. Similar comparison on 
trace metals and mineral accumulation between crabs and fishes harvested in the same water system at same period has been reported. The variation is also an indication of degree to which particular species pick up particulate matter from surrounding water aid in particular sediments while feeding Crabs are bottom feeder and are generally expected to concentrate more metals than surface feeders like fishes which are in agreement with earlier report. Therefore, crab is a very good consumable food with high nutritious value except for moderate amount of protein. The absence of major heavy metals may be due to the activities around the location of the river. The area consists mainly farmland and few residential houses. There are few or no industrial activities around the location.

\section{References}

1. Adeniyi AA, Yusuf KA, Okedeyi OO. Heavy metal determination in Rivers", Environmental Monitory Assessment 2008;137:451-458.

2. Baird D, Ulanowics RE. Determination of pollutants in Water", Mar Ecol prog Ser 1999;190:211-222

3. Burger J, Gochfeld M. "Heavy metals in commercial fish in New Jersey". Environ Res 2005;99:403-412.

4. Chukwujindu MA, Nwoso SO, Ossai EK, Nwajei GE. "Determination of heavy metals in Ojo River" Am J Food Tech 2008;(3):220-223

5. Ikem A, Egiebor NO, Nyavov K. International Occupational Safety and Health information Centre. Metals. (1999) In Basics of Chemical Safety, Chapter 7, Geneva: International Labour Organization. Water, Air, Soil, Pollut 2003;149:51-57

6. Odukoya OO, Ajayi SO. Waste Discharge", Nigeria J Nutritional Sci 1987;8(1):41-49

7. Lisa MS, Klaus N. Determination of Heavy Metals in Ojo River Applied and Environment Microbiology 2005, 71.

8. Smith SR, Jaffe DM, Skinner MA. Case report of metallic mercury injury". Pediatr. Emer. Care 1997.

9. WHO "Guidlines for Drinking-Water Quality", Second Edition, Addendum to Health Criteria and other supporting information, Geneva: World Health Organization 1998, 2. 